\title{
QUALIDADE DA EDUCAÇÃO DEBAIXO DO TAPETE
}

\section{SÉRGIO COSTA RIBEIRO*}

No dia 5 de fevereiro de 1992 uma pesquisa sobre a proficiência das crianças de 9 a 13 anos em 20 países do mundo, em matemática e ciências, foi divulgada oficialmente. A idéia desta pesquisa, já na sua segunda versảo, é avaliar o desempenho acadêmico dessas crianças em tópicos do conhecimento humano universal sem os quais os diversos países não poderäo competir no próximo século. Esta preocupação está deixando as teses acadêmicas para se tornar um tema tão ou mais importante que a própria sobrevivência da soberania dos países do planeta, dada a inevitável universalizaçāo da tecnologia moderna e do capital. Sem a educação competente de toda a população não haverá futuro para país nenhum.

Os procedimentos estatísticos para a seleçäo da amostra nos diversos países obedeceram a metodologias bastante sofisticadas, desenvolvidas a partir da experiência na área da mais importante instituição do mundo em avaliaçåo cognitiva, o ETS (Educational Testing Service). Esta instituição aplica hoje o famoso SAT (Scholastic Aptitude Test) que, desde 1926 avalia os estudantes do high school americano (equivalente ao nosso Segundo Grau) e que funciona como um termômetro do nível cognitivo do ensino fundamental americano. Estes testes padronizados permitem a comparação de um ano para outro, desde 1926, do desempenho dos estudantes americanos e constituem-se num dos

- Pesquisador Titnlar do Laboratorio Nacional de Computaçâo Clentffica (CNPq) e professor visitante do Instituto de Estudos Avançados da USP. 
principais indicadores na seleção dos candidatos para as mais importantes universidades daquele país. Hoje em dia são aplicados mais de seis milhões desses testes por ano. Quando a média do desempenho deste teste cai, milhỏes de dólares são aplicados pelo Ministério da Educaçăo americano no diagnóstico e na formulaçăo de recomendações ao sistema de ensino para que superem "a crise". Aqui a pesquisa foi aplicada e analisada pela Fundação Carlos Chagas, uma exemplar instituiçăo de pesquisa reconhecida por sua competência em todo o mundo civilizado.

A pesquisa em questăo pretendia avaliar uma amostra estatisticamente significativa dos habitantes desses países com as idades de 9a 13 anos. Nem todos os países, no entanto, conseguiram uma amostra representativa de toda a sua população nessas idades. O Brasil foi um deles. As razőes para isto são infelizmente muito desabonadoras para nosso sistema de ensino do Primeiro Grau. Em primeiro lugar os itens de testes preparados com a participação de todos os países envolvidos, requeriam em seu aspecto curricular que os alunos, no Brasil, estivessem cursando pelo menos a $5^{\mathrm{a}}$ série com 13 anos (o Brasil não participou da pesquisa com crianças de 9 anos). Aí começam nossos problemas: $50 \%$ de nossas crianças de 13 anos ainda nảo ingressaram nesta série devido às fantásticas taxas de repetência de nosso sistema de ensino. Como conseqüência, nossa população de referência para a seleção da amostra só poderia ser a metade de "melhor" desempenho dos alunos na populaçäo de 13 anos. É impressionante verificar que em nenhum outro país, com exceção de Portugal, onde $3 \%$ ainda freqüentavam essa série ("et pour cause"), havia alunos ainda na $5^{\mathrm{a}}$ série com 13 anos. Na maioria dos países, os alunos da amostra estavam cursando a $7^{\mathrm{B}}$ ou a $8^{\mathrm{a}}$ séries de seus sistemas de ensino.

Como apenas duas cidades do Brasil foram avaliadas, São Paulo e Fortaleza, a amostra brasileira não representa a populaçäo de 13 anos do país como um todo. Na realidade cada uma dessas cidades foi tratada, do ponto de vista da pesquisa, como "países" com restriçőes quanto à populaçâo estudantil, dado ao atraso curricular dos alunos devido à repetência. Isto fica claro quando observamos que apenas $20 \%$ dos alunos nas escolas paulistas da amostra não estavam ainda freqüentando a $5^{\mathbf{a}}$ série e $34 \%$ da amostra cearense. Vemos, portanto, que existe um razoável viés na direção das melhores escolas se tentarmos generalizar esta pesquisa para o país como um todo.

Vamos agora olhar o desempenho desses alunos em relação aos demais países.

Na matemática observamos que os nossos alunos obtiveram em média um desempenho muito baixo em relação aos demais países da pesquisa. Entre os 20 países ficamos apenas acima de Moçambique. Ê necessário lembrar que apenas $17 \%$ dos moçambicanos são alfabetizados contra $72 \%$ dos brasileiros. O mais assustador é constatar que os $5 \%$ melhores alunos da amostra de São Paulo obtiveram notas equivalentes a média da populaçåo inteira de 13 anos da 
Coréia, Formosa, Suíça, Uniảo Soviética (atualmente CEI) e Hungria. Em Fortaleza, os $5 \%$ de melhor desempenho estão abaixo da média desses países e próximos as médias de França, Itália, Israel e Canadá.

Em ciências os resultados não foram também muito animadores. Os nossos $5 \%$ melhores paulistas obtiveram notas equivalentes à média da Coréia e os cearenses abaixo da média de todos os alunos da Coréia, Formosa, Suíça, Hungria, ex-União Soviética, Eslovênia e Itália. A média em Fortaleza ficou abaixo do desempenho dos $10 \%$ piores alunos da Coréia, Formosa, Suíça e Hungria.

Diante desses alarmantes resultados e da altíssima repetência observada em nossa escola de Primeiro Grau, cabe perguntar:

. Como um sistema tão seletivo como o brasileiro (com tanta repetência) pode produzir estudantes de tão baixo desempenho?

. Por que resultados como estes não produzem nenhuma reação por parte da sociedade organizada e dos nossos dirigentes, enquanto nos países ocidentais, uma grande preocupação tomou conta das autoridades educacionais e açōes começam a ser implementadas diante do melhor desempenho dos países asiáticos?

. Como abrir a economia brasileira se, com este perfil educacional, jamais poderemos competir no mundo de hoje, e muito menos no do próximo século?

. Como aceitar o discurso oficial de programas de qualidade e competitividade industrial nesta situação?

. Como ver o escasso dinheiro público para a educação ser utilizado na construção de prédios desnecessários, em merenda escolar e em materiais didáticos que não conseguem ensinar sozinhos?

Esta crítica realidade educacional nos mostra que precisamos mudar nossos consensos sobre o sistema de ensino. $O$ alerta dessa pesquisa não pode ser rejeitado pelo ministro da Educação, que desqualificou as instituições envolvidas e a natureza dos testes comparando-os com uma "olimpíada" na qual o Brasil não teria enviado seus "atletas", como divulgado pelo jornal "O Estado de S. Paulo," em 9 de março de 1992.

Não há mais lugar para brincadeiras, para pagar professores com salários irrisórios, para aceitar a repetência como um fato normal e positivo e para fazer de conta que tudo vai bem. Ao contrário, são indicadores como estes que devem ser o ponto de partida para uma revolução não silenciosa e urgente em nosso sistema educacional. 


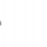

